\title{
IDENTIFIKASI DAN ESTIMASI SUMBER DAYA BATUBARA MENGGUNAKAN METODE POLIGON BERDASARKAN INTEPRETASI DATA LOGGING PADA LAPANGAN "ADA", SUMATERA SELATAN
}

\author{
Deddi Adrian*1, Bagus S. Mulyatno ${ }^{1}$ \\ J1 Prof. Dr. Sumantri Brojonegoro No.1 Bandar Lampung 35145 \\ Jurusan Teknik Geofisika, FT UNILA \\ e-mail: *19andreasdeddi14@gmail.com
}

\begin{abstract}
ABSTRAK
Seiring semakin menipisnya cadangan minyak bumi, tentu mendorong pemerintah untuk melakukan pencarian sumber energi baru. Ekplorasi batubara merupakan pilihan yang tepat karena potensinya yang begitu besar di Indonesia khususnya di Provinsi Sumatera Selatan diketahui memiliki kandungan 37,80\% dari total sumber daya di Indonesia. Metode well loggging adalah salah satu metode geofisika yang digunakan guna menemukan dan mengestimasi sumber daya barubara. Keunggulan dari metode well logging adalah mampu menggambarkan keadaan bawah permukaan secara lateral. Tujuan penelitian ini adalah menampilkan gambaran mengenai lapisan batuan bawah permukaan, menentukan arah sebaran dengan mengkorelasikan seam batubara antar sumur bor berdasarkan data logging, dan mengestimasi sumber daya batubara pada daerah penelitian. Luas daerah penelitian penulis sebesar $442.056 \mathrm{~m}^{2}$ memiliki 10 sumur bor. Data $\log$ yang digunakan dalam penelitian ini adalah log gamma ray dan log density, dimana lapisan batubara ditandai dengan respon log gamma ray dan respon log density yang rendah. Pada lapangan "ADA" ditemukan empat lapisan seam batubara, yaitu seam A1 dengan tebal 8,28 m, seam A2 dengan tebal 13,62 m, seam B dengan tebal 18,50, dan seam C dengan tebal 8,84. Arah sebaran batubara dari Selatan ke Utara dengan sudut kemiringan 5-30 dan arah kemenerusan dari Timur ke Barat. Penulis melakukan estimasi sumber daya batubara menggunakan metode poligon (area of influence) karena metode perhitungan ini dapat dilakukan dengan waktu yang singkat dan hasilnya tepat. Total batubara dengan metode poligon sebesar 18.322.653 $\mathrm{m}^{3}$ dalam tonase sebesar 21.987.184-27.483.980 ton sedangkan perhitungan dengan software rock works 15 sebesar $18.786 .254 \mathrm{~m}^{3}$ dalam tonase sebesar 22.543.505-28.179.381 ton.
\end{abstract}

\begin{abstract}
As petroleum reserves depleted, certainly encourage the government to search for new energy sources. Eksploration of coal is the right choice because its potential is so great in Indonesian especially in South Sumatera Province is known have content 37,80\% from total resources in Indonesian. Well loggging method is one of geophysics method used to find and estimate coal resources. Advantages of well logging method is able to describe subsurface laterally. The purpose of this study is displaying an overview of subsurface rock layers, determine the direction of distribution by correlating coal seam between wells based on data logging, and to estimate coal resources in the research area. The total area of the author's research is $442.056 \mathrm{~m}^{2}$ has 10 wells. Log data used in this study is gamma ray log dan density log, where coal seams are characterized by gamma ray $\log$ response and low $\log$ density responses. On the field "ADA" found four coal seam, that is seam A1 with thickness 8,28 m, seam A2 with thickness 13,62 m, seam B with thickness 18,50, and seam C with thickness 8,84 . Direction of coal distribution from South to North with slope angle 5-30 and direction of sincerity from East to West. The author calculates the estimated coal resource using polygon method because this calculates method can be done with a short time and the results are right. Total coal by polygon method of $18.322 .653 \mathrm{~m}^{3}$ in tons of 21.987.184-27.483.980 ton while calculations with software rock works 15 amount $18.786 .254 \mathrm{~m}^{3}$ in tons of 22.543.505-28.179.381 ton.
\end{abstract}

Keywords - Coal, well logging, seam, resources, polygon method 


\section{PENDAHULUAN}

Indonesia merupakan salah satu negara dengan tingkat konsumsi bahan bakar minyak tertinggi di dunia. Meningkatnya konsumsi energi bahan bakar minyak tersebut tidak diimbangi oleh cadangan minyak bumi yang menipis. Hal tersebut mendorong pemerintah untuk melakukan pencarian sumber energi baru untuk menjamin ketahanan energi di masa mendatang. Eksplorasi batubara merupakan pilihan yang tepat karena masih menyimpan potensi yanng besar untuk dilakukan penambangan (Julkipli dkk, 2015).

Batubara adalah batuan sedimen yang dapat terbentuk dari endapan organik, yang utamanya adalah sisa-sisa tumbuhan dan terbentuk melalui proses pembatubaraan. Potensi batubara di Indonesia yang bergitu besar bisa menjadi alt ernatif energi seiring terus berkurangnya bahan bakar minyak bumi. Sumber daya batubara di Indonesia diperkirakan sebesar 61,366 miliar ton dan tersebar di Sumatera, Kalimantan, dan sisanya di Jawa, Sulawesi dan Irian Jaya. Terkhusus di Provinsi Sumatera Selatan, potensi batubara diketahui memiliki kandungan sebesar $37,80 \%$ daru total sumber daya yang terkandung di Indonesia, sekitar 23,198 miliar ton (Tim Kajian Batubara Nasional, 2006).

Metode well logging adalah suatu metode geofisika yang merekam besaranbesaran fisis batuan di sumur pemboran yang biasanya dilakukan dari dasar sumur kemudian ditarik ke atas secara perlahanlahan dengan maksud agar sensor atau probe yang diturunkan ke dalam sumur lubang bor dapat mendeteksi lapisan batuan di dinding sumur bor. Keunggulan dari metode well logging adalah mampu menggambarkan keadaan bawah permukaan secara vertikal, sehingga litologi masing-masing lapisan dapat tergambar dengan jelas.

Dalam penelitian ini, penulis menganilisis sebaran batubara dan mengestimasi sumber daya batubara pada lapangan "ADA", Sumatera Selatan dengan menggunakan metode well logging untuk analisis respon log-nya guna mendapatkan gambaran bawah permukaan secara lateral yang akurat, sedangkan untuk mengestimasi sumber daya batubara penulis menggunakan metode perhitungan poligon. Metode poligon dipilih karena sangat cocok untuk kondisi geologi Lapangan "ADA" yang sederhana dan perhitungannya relatif cepat dengan hasilnya relatif tepat.

\section{TINJAUAN PUSTAKA}

\subsection{Stratigrafi Daerah Penelitian}

Daerah penelitian penulis yaitu Lapangan "ADA" termasuk dalam Formasi Muara Enim. Stratigrafi pada Formasi Muara Enim dibagi menjadi empat subbagian, yang diberi nama (dari bawah ke atas), yaitu M1, M2, M3, dan M4 seperti yang tertera pada Gambar 1.

Dari ke-empat sub-bagian tersebut, sub bagian M2 mayoritas mengandung sumber daya batubara di Desa Tanjung Enim, lapisan-lapisan tersebut diberi nama dengan urutan dari bawah yang potensial untuk ditambang ada beberapa lapisan batubara utama. Adapun nama sub-lapisan M2 dari yang berumur tua sampai dengan berumur muda, yaitu:

\subsubsection{Lapisan Petai (Batubara Seam C)}

Lapisan batubara ini mempunyai ketebalan antara 6-10 m, dan dijumpai sisipan tipis batu lempung/batulanau karbonan dimana beberapa tempat mengalami pemisahan (split) menjadi $\mathrm{C} 1$ dan $\mathrm{C} 2$ dengan ketebalan masing-masing 5,0 dan 10,1 m. Di atas lapisan batubara $\mathrm{C}$ ini dittutupi oleh batupasir lanauan yang sangat keras dengan ketebalan 25,0-44,0 $\mathrm{m}$. 


\subsubsection{Lapisan Suban (Batubara Seam B)}

Lapisan Suban memiliki ketebalan sekitar $17,0 \mathrm{~m}$ di beberapa tempat mengalami pemisahan (split) menjadi B1 dan B2 dengan ketebalan masing-masing 8,0-14,55 m dan 3,0-5,8 m. Diantara kedua lapisan ini dijumpai batulempung dan batulanau dengan tebal 2,0-5,0 $\mathrm{m}$ (disebut interburden B2-B1), sedangkan di atas lapisan batubara B atau B1 ditutupi oleh batu lempung dengan ketebalan 15,0-23,0 $\mathrm{m}$ yang berinterklasi dengan batu pasir dan batulanau (disebut interburden B2-B1), sedangkan di atas lapisan batubara B atau B1 ditutupi oleh batulempung dengan ketebalan 15,0-23,0 m yang berinterkalasi dengan batupasir dan batulanau (disebut interburden B1-A2) serta dijumpai adanya lapisan tipis $(0,4-0,6 \mathrm{~m})$ batubara atau batulempung karbonan yang dikenal dengan istilah Suban Marker.

\subsubsection{Lapisan Mangus Lower (Batubara Seam A2)}

Lapisan Mangus Lower memiliki ketebalan sekitar 9,8-14,7 m dijumpai sisipan tipis batulempung sebagai lapisan pengotor (clayband). Di atas lapisan batubata A2 ini ditutupi oleh batulempung tuffaan dengan ketebalan 2-5 m disebut sebagai interburden A2-A1.

\subsubsection{Lapisan Mangus Upper (Batubara Seam A1)}

Lapisan Mangus Upper memiliki ketebalan sekitar 5,0-13,25 m. Di atas lapisan batubara A1 ini ditutupi oleh batulempung bentonitan dengan ketebalan sekitar 70-120 m disebut sebagai sebagai overburden A2-A1, dimana pada lapisan penutup ini dijumpai adanya lapisan batubara yang dikenal sebagai lapisan batubara gantung (Hanging Seam). Deskripsi penampang litologi Lapangan
"ADA" secara lengkap yang dapat dilihat pada Gambar 2.

\section{TEORI DASAR}

\subsection{Proses Pembentukan Batubara}

Batubara berasal dari tumbuhan yang disebabkan karena adanya proses-proses geologi, kemudian berbentuk endapan batubara yang dikenal sekarang ini. Bahanbahan tumbuhan mempunyai komposisi utama yang terdiri dari karbon dan hidrogen. Selain itu, terdapat kandungan mineral nitrogen. Substansi utamanya adalah cellulose yang merupakan bagian dari selaput sel tumbuhan yang mengandung karbohidrat yang tahan terhadap perubahan kimiawi.

Vegatasi pada lingkungan tersebut mati kemudian terbentuklah peat (gambut). Kemudian gambut tersebut mengalami kompresi dan pengendapan di antara lapisan sedimen dan juga mengalami kenaikan temperatur akibat geothermal gradient. Akibat proses tersebut maka akan terjadi pengurangan porositas dan pengurangan moisture sehingga terlepasnya grup $\mathrm{OH}, \mathrm{COOH}, \mathrm{OCH}_{3}$, dan $\mathrm{CO}$ dalam wujud cair dan gas. Karena banyaknya unsur oksigen dan hidrogen yang terlepas maka unsur karbon relatif bertambah yang mengakibatkan terjadinya lignit (brown coal). Kemudian dengan adanya kompresi yang terus menerus serta kenaikan temperatur maka terbentuklah batubara sub-bituminus dan bituminus dengan tingkat kalori yang lebih tinggi dibandingkan dengan brown coal.

Bumi tidak pernah berhenti, oleh karena itu kompresi terus berlangsung diiringi bertambahnya temperatur sehingga moisture sangat sedikit serta unsur karbon yang banyak merubah batubara sebelumnya ke tingkat yang lebih tinggi, yaitu antrasit yang merupakan kasta tertinggi pada batubara (Cook, 1982). Proses Pembentukan batubara sendiri dapat dilihat pada Gambar 3. 


\subsection{Tempat Terbentuknya Batubara}

Berdasarkan tempat terbentuknya, batubara dikenal dua teori, yaitu:

\section{a. Teori Insitu}

Teori insitu mengatakan bahwa bahanbahan pembentuk lapisan batubara, terbentuk dimana tumbuh-tumbuhan asal itu berada. Jenis batubara yang terbentuk dengan cara ini mempunyai penyebaran luas dan merata kualitasnya, karena abunya relatif kecil. Teori insitu dapat ditemukan di lapangan batubara Muara Enim, Sumatera Selatan.

\section{b. Teori Drift}

Teori drift menyebutkan bahwa bahanbahan pembentuk lapisan batubara terjadi di tempat yang berbeda dengan tempat tumbuhannya semua hidup dan berkembang. Jenis batubara yang terbentuk dengan cara ini mempunyai penyebaran tidak luas, tetapi dijumpai di beberapa tempat, kualitas kuarang baik. Teori drift dapat ditemukan di lapangan batubara delta Mahakam purba, Kalimantan Timur (Sukandarrumidi, 1995).

\subsection{Sumber Daya dan Cadangan Batubara}

Sumber daya dan cadangan batubara yang ada di Indonesia seperti yang dijelaskan oleh SNI pada tahun 1998, yaitu:

\section{a. Sumber Daya Batubara}

Berdasarkan tahap penyelidikan, sumber daya mineral dikelompokkan menjadi empat kategori, yaitu:

1. Sumber Daya Batubara Hipotetik

2. Sumber Daya Batubara Tereka

3. Sumber Daya Batubara Terunjuk

4. Sumber Daya Batubara Terukur

\section{b. Cadangan Batubara}

Cadangan batubara dikelompokkan menjadi dua kategori, yaitu:
1. Cadangan Batubara Terkira

2. Cadangan Barubara Terbukti (SNI, 1998).

\subsection{Metode Well Logging}

Log adalag suatu grafik kedalaman (bisa juga waku), dari satu set data yang menunjukkan parameter yang diukur secara berkesinambungan di dalam sebuah sumur (Harsono, 1997). Kegiatan untuk mendapatkan data log disebut "logging". Logging mmberikan data yang diperlukan untuk mengevaluasi secara kuantitatif banyaknya sumber daya di lapisan pada situasi dan kondisi yang sesungguhnya. Gragik log memberikan informasi yang dibutuhkan untuk mengetahui sifat-sifat batuan dan cairan (Eilis and Singer, 1987).

Intepretasi data log merupakan suatu metode pendukung dalam usaha evaluasi formasi, yaitu dengan cara menggunakan hasil perekaman alat survey logging sebagai sumber informasi yang utama. Intepretasi dapat dilakukan baik secara kualitatif maupun kuantitatif (Dewanto, 2009).

\subsection{Perangkat-Perangkat Well Logging}

Terdapat beberapa perangkat well logging yang digunakan penulis dalam penelitian ini diantaranya adalah:

\section{a. Log Gamma Ray}

Prinsip dari log gamma ray adalag perekaman radioaktif alami bumi. Setiap GR yanng terdeteksi akan menimbulkan pulsa listrik pada detektor. Parameter yang direkam adalah jumlah dari pulsa yang tercatat per satuan waktu (Harsono, 1997). Secara khusus log gamma ray berguna untuk mengetahui lapisan permeabel dan impermeable.

\section{b. $\log$ Densitas}


Prinsip kerja $\log$ densitas, yaitu sumber radioaktif dari alat pengukuran dipancarkan sinar gamma dengan intensitas energi tertentu menembus formasi/batuan. Dalam log densitas kurva dinyatakan dalam satuan $\mathrm{gr} / \mathrm{cc}$, karena energi yang diterima untuk deflektor dipengaruhi oleh matrik batuan ditambah kandungan yang ada dalam pori batuan, maka satuan gr/ccc merupakan besaran bulk density ( $\mathrm{pb}$ ). Beberapa respon yang khas pada log densitas dalam satuan gr/cc dapat dilihat pada Gambar 5.

\subsection{Intepretasi Well Logging}

Intepretasi data log geofisika dilakukan untuk menetukan litologi pada setiap kedalama di bawah permukaan. Karakteristik $\log$ dari beberapa batuan yang melibatkan log gamma ray dan log density adalah sebagai berikut:

a. Batubara; gamma ray rendah dengan densitas rendah.

b. Batulempung; gamma ray menengah dengan densitas menengah.

c. Batupasir; gamma ray agak rendah dengan densitas menengah.

d. Batu Konglomerat; gamma ray menengah dengan densitas menengah.

e. Batugamping; gamma ray rendah dengan densitas menengah sampai tinggi.

f. Batuan vulkanik; gamma ray rendah dengan densitas tinggi.

\subsection{Metode Poligon}

Metode poligon merupakan metode perhitungan yang konvensional dibandingkan dengan metode lainnya, karena pada pergitungan cadangan endapannya tidak begitu memperhatikan struktur patial daerah yang akan diobservasi dan tidak begitu memperhatikan data dari titik bor sekitarnya. Sebelum melakukan perhitungan dengan metode poligon terlebih dahulu diketahui variabel yang mempengaruhi perhitungan, diantaranya:

a. Luas blok/poligon yang akan dihitung.

b. Ketebalan endapan batuan pada lubang bor yang terletak pada blok yang akan dihitung cadangan endapan batubara.

c. SG (Spesific Gravity) batubara yang terletak pada blok yang akan dihitung.

Adapun kelebihan dan kekurangan perhitungan menggunakan metode poligon, yaitu:

a. Kelebihan

1. Perhitungan dapat dilakukan dalam waktu singkat.

2. Cocok untuk yang tidak bervariasi.

3. Hasilnya lebih tepat apabila ketebalan batubara relatif seragam.

b. Kekurangan

1. Kurang tepat untuk yang bervariasi (inconsistent bed) (Hurstrulid and Kutcha, 1995).

\section{METODE PENELITIAN}

\subsection{Tempat dan Waktu Penelian}

Penelitian ini dilakukan di Divisi Geologi, Satuan Kerja Eksplorasi dan Geoteknik, PT. Bukit Asam (Persero) Tbk. dan di Laboratorium Teknik Geofisika, Universitas Lampung.

Alat dan bahan yang digunakan selama penelitian ini berlangsung adalah data rekaman $\log (*$.LAS file), peta sebaran titik bor, peta topografi daerah penelitian, Software WellCAD 4.3., Software Rock Works 15, kertas milimeter blok, dan Personal Computer (PC).

\subsection{Alur Penelitian}

Adapun alur penelitian yang penulis lakukan dalam penelitian ini, yaitu:

1. Studi literatur berkenaan dengan batubara, metode well logging (log gamma ray, dan log density), perhitungan metode poligon, geologi regional Sumatera Selatan dan 
peneltiian sebelumnya di regional Sumatera Selatan.

2. Persiapan data meliputi pengumpulan data yang telah dimiliki oleh PT. Bukit Asam (Persero), Tbk. dari hasil pengeboran, yakni peta sebaran titik bor dan data rekaman lognya..

3. Pengolahan data dilkaukan dengan software WellCAD untuk mendapatkan tampilan grafik logging sumur yang terdiri dari log gamma ray dan log density. Grafik log diintepretasi litologi batuannya berdasarkan range nilai log gamma ray dan log density. Selanjutnya mengkorelasikan litologi guna mengetahui penyebaran lapisan batubara dan arah kemenerusannya serta terakhir menghitung sumber daya batubara pada Lapangan "ADA", Sumatera Selatan menggunakan perhitungan metode poligon dan software Rock Works 15.

\subsection{Diagram Alir Penelitian}

Adapun diagram alir dalam penelitian ini ditunjukkan pada Gambar 7.

\section{HASIL DAN PEMBAHASAN}

\subsection{Sebaran Titik Bor}

Penelitian ini dilakukan di daerah Izin Usaha Pertambangan (IUP) milik PT. Bukit Asam (Persero), Tbk., tepatnya pada Lapangan "ADA", Sumatera Selatan dengan luasan sebesar $442.056 \mathrm{~m}^{2}$ dengan jumlah titik bor berjumlah sepuluh titik bor dengan elevasi dan kedalaman titik bor yang bervariasi.

\subsection{Intepretasi Litologi dari Data Log Geofisika}

Dalam menganalisa data well logging dari setiap titik bor dilakukan pengolahan data berupa peraturan tampilan atau smoothing menggunakan Software WellCAD 4.3. Berdasarkan kontras sifat fisik batubara terhadap batuan lainnya, batubara bersifat permeabel dan memiliki nilai densitas yang rendah, sehingga dalam perekaman log geofisika respon $\log$ gamma ray akan menunjukkan nilai yang sangat rendah berkisar $0-10$ CPS dan respon log density yang sangat tinggi dalam satuan CPS. Pada Gambar 9 (a). merupakan respon log gamma ray dan log density yang merupakan lapisan batubara.

Sedangkan untuk respon log gamma ray dan log density untuk litologi clayband dapat dilihat pada Gambar 9 (b). Clayband sendiri merupakan lapisan pengotor yang terdapat di dalam batubara. Biasanya berupa batuanlempung atau batuanpasir. Ketebalan dari clayband sendiri berkisar antara 0-30 cm.

\subsubsection{Intepretasi Litologi Titik Bor MT_106}

Pada titik bor MT_106 dengan kedalaman $150 \mathrm{~m}$ ditemukan seam batubara A1 dengan ketebalan 9,33 m mengandung $99,36 \%$ batubara, seam A2 dengan ketebalan 14,42 m mengandung $100 \%$ batubara, seam B dengan ketebalan $20 \mathrm{~m}$ mengandung $99,20 \%$ batubara, dan seam $C$ dengan ketebalan 9,40 m mengandung $97,88 \%$ batubara.

\subsubsection{Intepretasi Litologi Titik Bor MT_107}

Pada titik bor MT_107 dengan kedalaman 27,47 $\mathrm{m}$ ditemukan seam batubara $\mathrm{C}$ dengan ketebalan 8,95 m mengandung $97,10 \%$ batubara.

\subsubsection{Intepretasi Litologi Titik Bor MTG_19}

Pada titik bor MTG_19 dengan kedalaman 199,52 m ditemukan seam 
batubara A1 dengan ketebalan 8,67 m mengandung 99,08\% batubara, seam A2 dengan ketebalan 12,96 m mengandung $100 \%$ batubara, seam B dengan ketebalan 17,92 m mengandung $98,16 \%$ batubara.

\subsubsection{Intepretasi Litologi Titik Bor MTG_20}

Pada titik bor MT_106 dengan kedalaman 199,32 m ditemukan seam batubara A1 dengan ketebalan 7,98 m mengandung 98,50\% batubara, seam A2 dengan ketebalan 13,02 m mengandung $99,70 \%$ batubara, seam B dengan ketebalan 17,80 m mengandung 98,54\% batubara.

\subsection{Analisa Nilai Gamma Ray dan Nilai Density Pada Seam Batubara}

Analisa nilai gamma ray dan nilai density sangat penting dalam menentukan range nilai terhadap penentuan litologi pada titik bor. Hal ini dikarenakan penulis berasumsi bahwa range nilai pada suatu litologi bersifat konstans sehingga hasil analisa nilai gamma ray dan nilai density dapat menjadi acuan. Data yang digunakan yaitu informasi hasil intepretasi nilai gamma ray dan nilai density pada masingmasing seam batubara pada keempat titik bor yang telah penulis intepretasi.

Dari hasil analisa nilai gamma ray dan nilai density pada keempat titik bor pada Lapangan "ADA", Sumatera Selatan didapatkan pada batubara seam A1 memiliki range gamma ray dari 0,00-11,00 API, dan range density dari 1,81-2,35 $\mathrm{gr} / \mathrm{cc}$. batubara seam A2 memiliki range gamma ray dari 0,00-9,67 API, dan range density dari 1,86-2,34 gr/cc. batubara seam B memiliki range gamma ray dari $0,00-$ 11,00 API, dan range density dari 1,78$2,18 \mathrm{gr} / \mathrm{cc}$. batubara seam $\mathrm{C}$ memiliki range gamma ray dari 0,00-10,50 API, dan range density dari 1,75-1,96 gr/cc.

\subsection{Korelasi Litologi Titik Bor}

Dalam penelitian ini, penulis melakukan korelasi litologi menggunakan data titik bor serta jarak masing-masing titik bor seperti pada Peta Cross Line Lapangan "ADA", Sumatera Selatan. Penulis melakukan dua korelasi dalam penelitian ini, korelasi berdasarkan garis key bed seam A1 dan korelasi berdasarkan datum elevasi $0 \mathrm{~m}$ dengan mengikuti enam cross line untuk sebagai acuan, dimana tiga cross line membentang dari Selatan ke Utara, yaitu cross line A-A', cross line $\mathrm{B}-$ $\mathrm{B}$ ', dan cross line $\mathrm{C}-\mathrm{C}$ ' dan tiga cross line lagi membentang dari Barat ke Timur, yaitu cross line D-D', cross line E-E', dan cross line F-F'. Skala pada peta cross line 1:1000, dimana satu centimeter mewakili sepuluh meter dalam keadaan sebenarnya.

Seperti yang sudah dijelaskan di atas, garis key bed yang penulis pakai adalah garis roof dari seam A1. Hal ini dikarenakan setiap titik bor terdapat lapisan lapisan seam A1. Hasil yang didapatkan dari korelasi setiap litologi pada titik bor yaitu kemenerusan lapisan seam batubara baik seam A1, seam A2, seam B, dan seam $\mathrm{C}$ terlihat jelas. Hal ini dapat dilihat dari ketebalan masing-masing lapisan seam batubara memiliki ketebalan yang relatif sama.

Hasil yang didapat dari korelasi setiap litologi pada titik bor berdasarkan datum elevasi yaitu penulis mengetahui pola sebaran batubara di Lapangan "ADA" serta mengetahui sudut kemiringan batubara. Dapat disimpulkan bahwa lapisan seam batubara memiliki pola sebaran batubara dengan arah kemenerusan dari arah Timur ke Barat, sedangkan kemiringan lapisan batubara dari arah Selatan ke Utara dengan sudut kemiringan sebesar $5-30^{\circ}$, sehingga penulis mengasumsikan batubara yang berada di Utara relatif lebih dalam posisinya dibandingkan batubara yang berada di Selatan. 


\subsection{Perhitungan Sumber Daya Batubara}

Setelah mengintepretasikan dan mengkorelasikan setiap litologi pada titik bor, penulis menghitung sumber daya batubara pada Lapangan "ADA", Sumatera Selatan dengan menggunakan metode poligon dan dibantu dengan perhitungan dan pemodelan dalam bentuk 3D menggunakan software rock work 15 .

\subsubsection{Perhitungan Sumber Daya Batubara Menggunakan Metode Poligon.}

Salah satu cara untuk menghitung sumber daya batubara pada suatu daerah adalah metode poligon. Metode poligon atau yang dikenal dengan metode area of influence dipilih oleh penulis dalam menghitung sumber daya batubara dikarenakan metode ini cocok untuk melakukan perhitungan dalam waktu yang singkat dan daerah penelitian penulis. Dimana Lapangan "ADA", Sumatera Selatan termasuk kategori lokasi tambang yang endapannya relatif homogen dan mempunyai geometri yang sederhana.

Berdasarkan hasil yang diperoleh setelah dilakukan perhitungan sumber daya batubara dengan menggunakan metode poligon, dapat diketahui bahwa jumlah sumber daya batubara pada seam A1 sebesar 2.546.531 $\mathrm{m}^{3}$, sumber daya batubara pada seam A2 sebesar 4.490.855 $\mathrm{m}^{3}$, sumber daya batubara pada seam B sebesar 7.497.921 $\mathrm{m}^{3}$, dan sumber daya batubara pada seam C sebesar 3.787.348 $\mathrm{m}^{3}$. Total perhitungan sumber daya batubara pada Lapangan "ADA" sebesar 18.322.653 $\mathrm{m}^{3}$ dan apabila dikonversi dalam satuan ton maka didapat sebesar 21.987.184 - 27.483.980 ton.

\subsubsection{Perhitungan Sumber Daya Batubara Menggunakan Software Rock Works 15.}

Software Rock Works 15 merupakan salah satu software geofisika yang bisa digunakan untuk menghitung sumber daya, cadangan suatu mineral dengan bantuan informasi yang didapat dari data titik bor. Input yang digunakan dalam software ini meliputi data lokasi penelitian (easting, northing, depth, dan elevasi), data titik bor dimiliki (easting, northing, depth, dan elevasi) serta litologi batuan pada titik bor dan kedalaman masing-masing litologi tersebut.

Setelah dilakukan pemodelan semua litologi yang terdapat pada Lapangan "ADA", Sumatera Selatan (Gambar 12.), litologi yang dominan adalah litologi batulanau, dimana pada lokasi tersebut mengandung batuanlanau sebesar 36\% sedangkan batubara sendiri sekitar $21 \%$ dari total keseluruhan.

Dari hasil perhitungan yang didapatkan dengan metode poligon maupun dengan menggunakan software rock works 15 tidak memiliki selisih yang jauh, yaitu sebesar $463.601 \mathrm{~m}^{3}$ dan dalam satuan ton memiliki selisih 556.321 695.401 ton atau dalam satuan persen sebesar $2,53 \%$, dimana selisih tersebut dianggap masih batas tolerasi karena selisih perhitungan tidak lebih dari $10 \%$.

\section{KESIMPULAN}

Terdapat lima jenis litologi pada lapangan "ADA", Sumatera Selatan yaitu batupasir, batulempung, batulanau, batulempung tuffan, dan batubara.

Pada Lapangan "ADA" ditemukan empat lapisan seam batubara, yaitu seam A1 dengan ketebalan $8,28 \mathrm{~m}$, seam A2 dengan ketebalan 13,62 m, seam $\mathrm{B}$ dengan ketebalan 18,50 m, dan seam $\mathrm{C}$ dengan ketebalan 8,84.

Korelasi litologi berdasarkan garis key bed diketahui bahwa lapisan batubara relatif konstan. Sedangkan korelasi litologi berdasarkan datum elevasi diketahui bahwa kemenerusan lapisan seam batubara 
relatigf dari arah Timur ke Barat dan kemiringan lapisan batubara antara satu seam dengan seam lainnya dari arah Selatan ke Utara dengan sudut kemiringan 5-30

Dari perhitungan menggunakan metode poligon, didapatkan total sumber daya batubara pada Lapangan "ADA", Sumatera Selatan sebesar $18.323 .000 \mathrm{~m}^{3}$ dan dalam ton sebesar 21.987.000 27.484.000 ton. Sedangkan hasil perhitungan dengan software rock works 15 didapatkan total sumber daya batubara pada Lapangan "ADA", Sumatera Selatan sebesar $18.786 .000 \mathrm{~m}^{3}$ dan dalam tonase sebesar 22.544.000 - 28.179.000 ton.

\section{DAFTAR PUSTAKA}

BPB manual.1981. British Petroleum Book. British Company. United Kingdom.

Cook, A. C. 1982. The Origin and Petrology of Organic Matter in Coals, Oil, Shales, and Petroleum Source-Rock. Australia: Geology Departement of Wollonggong University. Ltd. Malta.

Dewanto, O. 2009. Well Logging Vol-6. DIKTAT. Lampung: Universitas Lampung.

Eilis, D.V. and Singer, J. M. 1987. Well Logging for Earth Scientist $2^{\text {nd }}$ edition. Springer. Netherlands.

Harsono, A. 1997. Penghantar Evaluasi Log. Jakarta: Schlumberger Oilfield Service.

Hurstrulid, W., and Kuchta, M. 1995. Open Pit Mine Planning \& Design Vol. I. A.A.Balkema, Rotterdam.

Julkipli, Siregar, S. S., and Sota, I. 2015. Intepretasi Sebaran Batubara Berdasarkan Data Well Logging di Daerah Blok X Pulau Laut Tengah Kabupaten Kotabaru. Jurnal Fisika Flux, Vol. 12 No. 1. Universitas
Lambung Mangkurat: Program Studi Fisika FMIPA.

PT. Bukit Asam (Persero), Tbk. 2007. Laporan Internal Pemboran Eksplorasi dan geophysical Logging. Satuan Kerja Unit Eksplorasi Rinci. Tidak dipublikasikan.

Rider, M. 1996. The Geological Intepretation of Well Logs $2^{\text {nd }}$ Edition. Malta: Inteprint Ltd. 


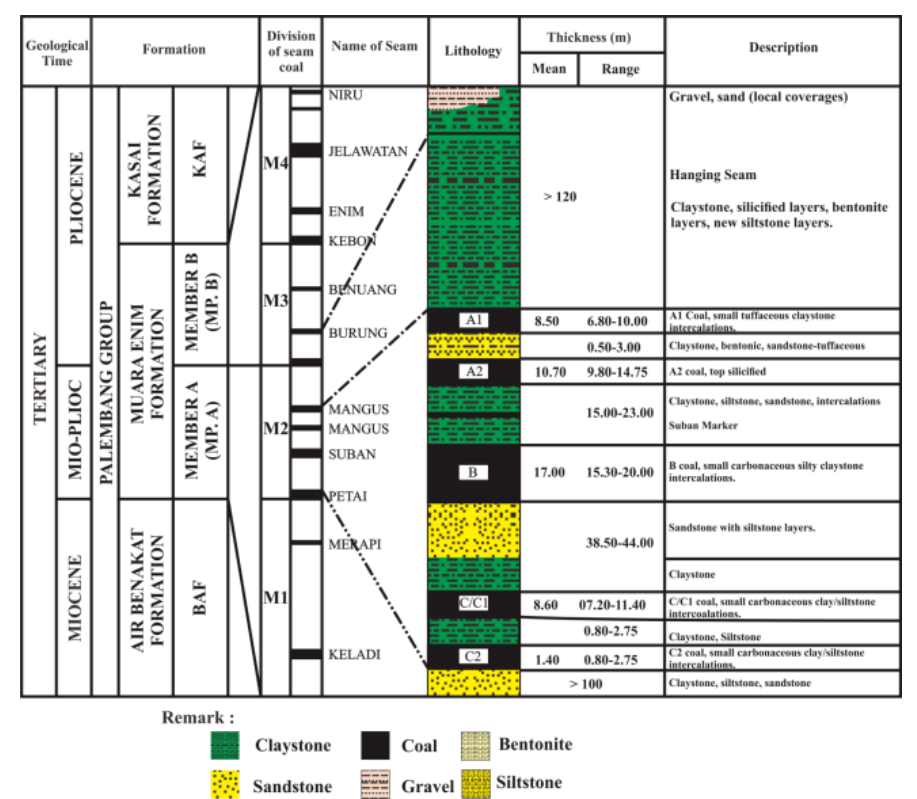

Gambar 1. Sekuan Stratigrafi dan Kolom Litologi Formasi Muara Enim (Tanpa Skala) (PT. Bukit Asam, 2007).

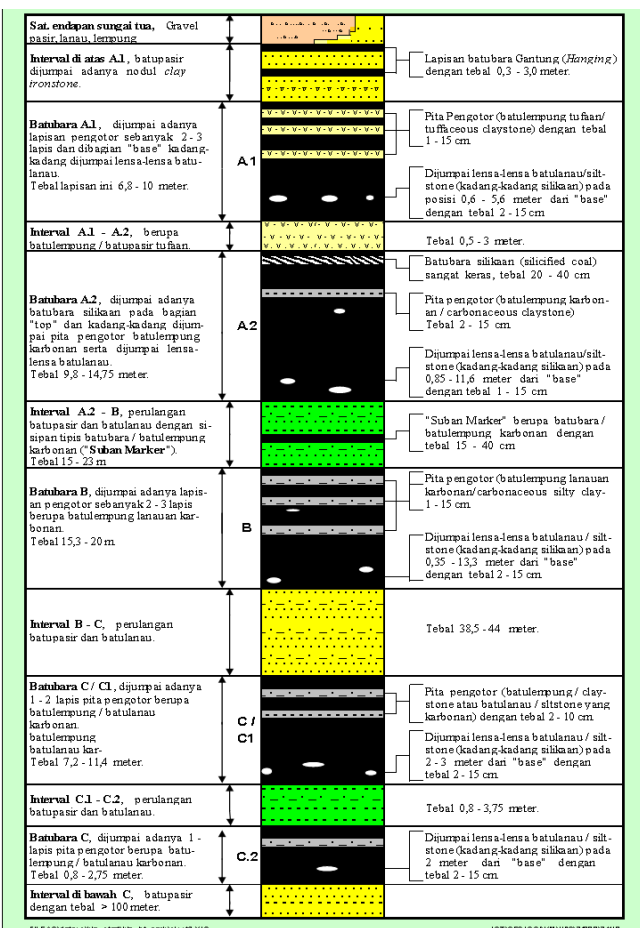

Gambar 2. Penampang Litologi Lapangan "ADA" (Tanpa Skala) (PT. Bukit Asam, 2007).

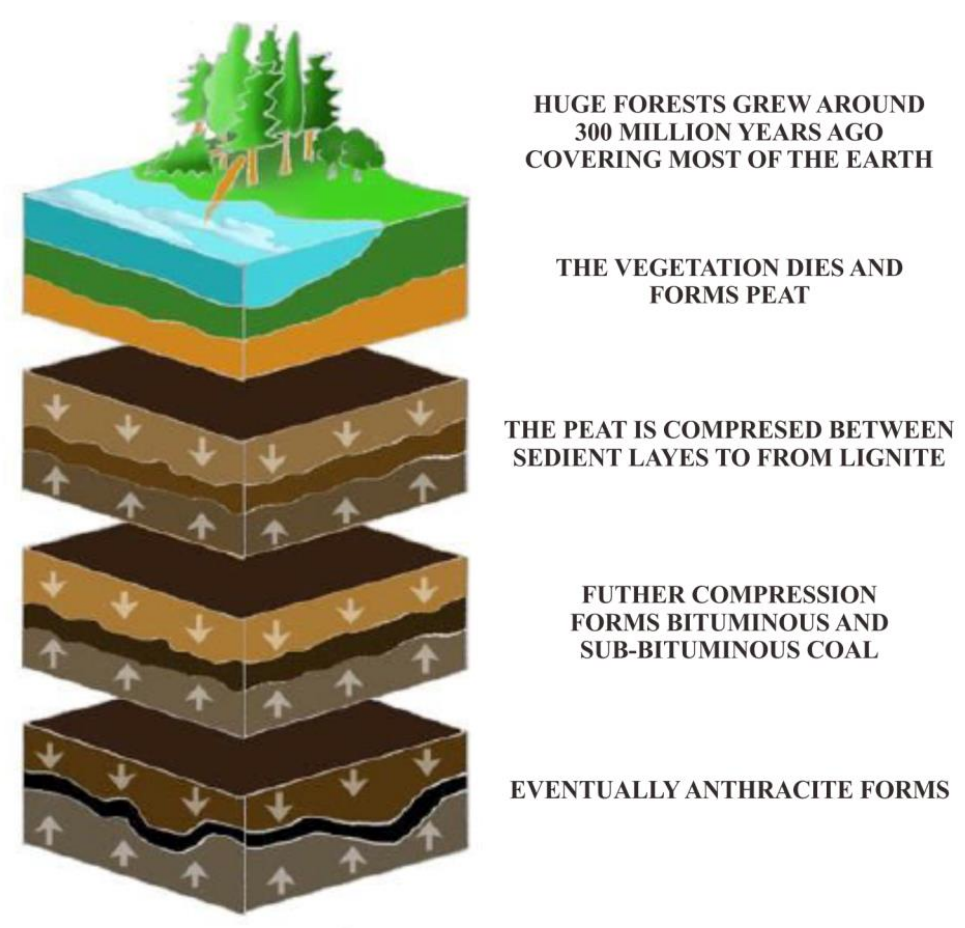

Gambar 3. Proses Pembentukan Batubara (Cook, 1982). 


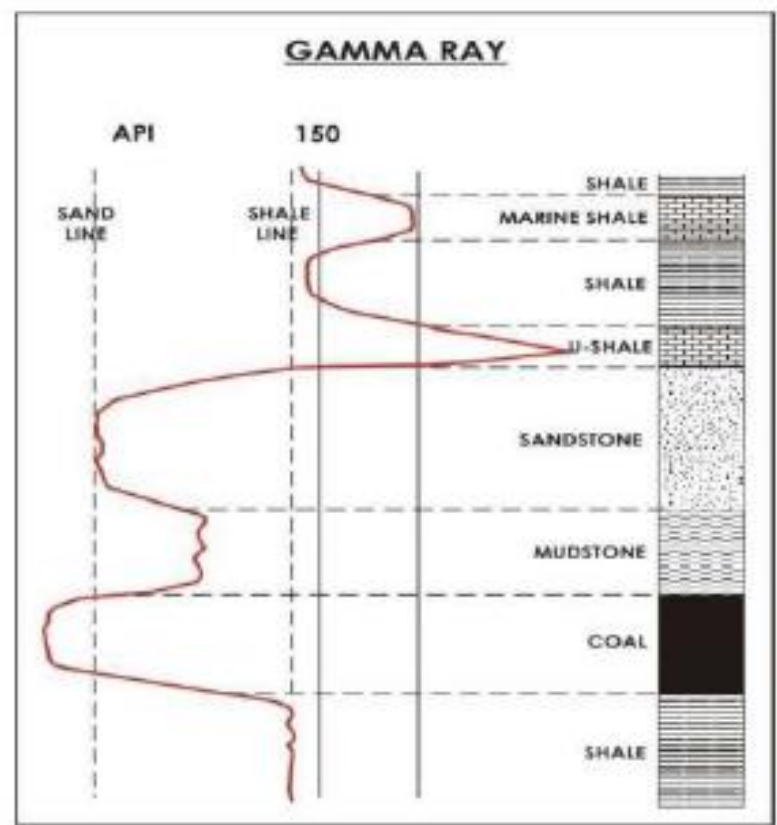

Gambar 4. Penentuan Penarikan Sand Base Line dan Shale Base Line (BPB Manual, 1981).

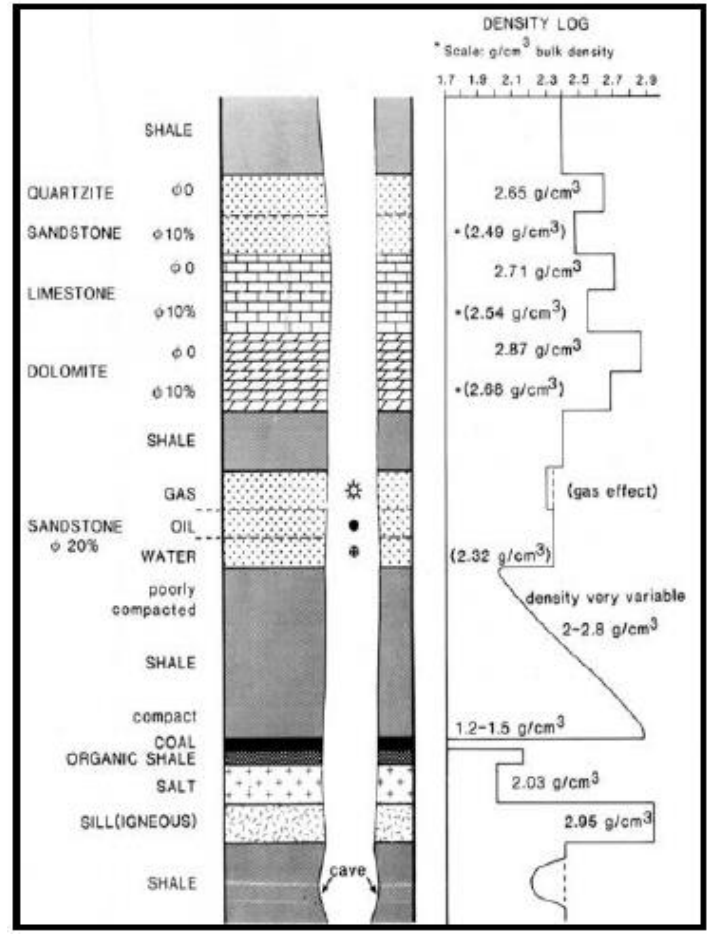

Gambar 5. Respon Log Densitas Terhadap Beberapa Jenis Batuan Dengan Densitas Total dari Batuan Meliputi Matriks Padat Dan Fluida yang Mengisi Pori (Rider, 1996).

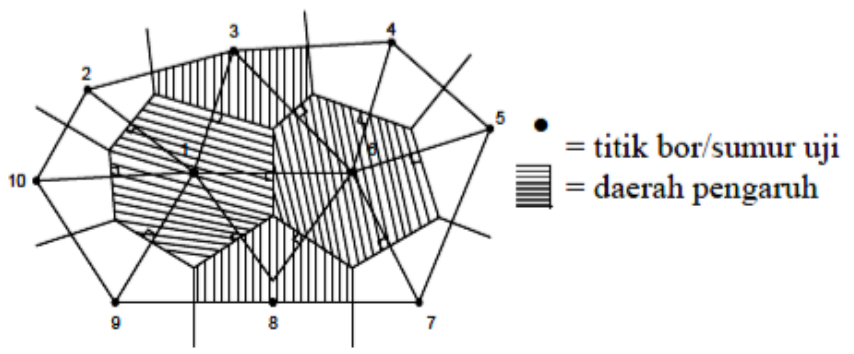

Gambar 6. Skema Perhitungan Metode Poligon (Hustrulid and Kutcha, 1995). 


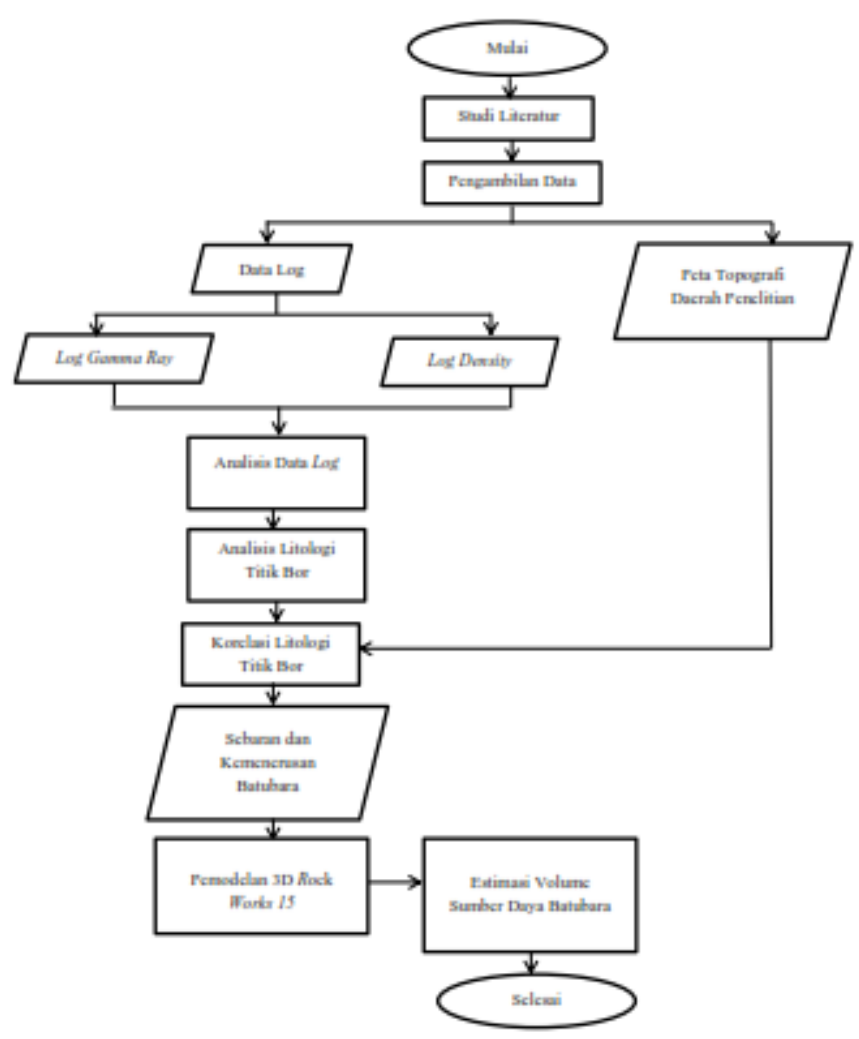

Gambar 7. Diagram Alir Penelitian.

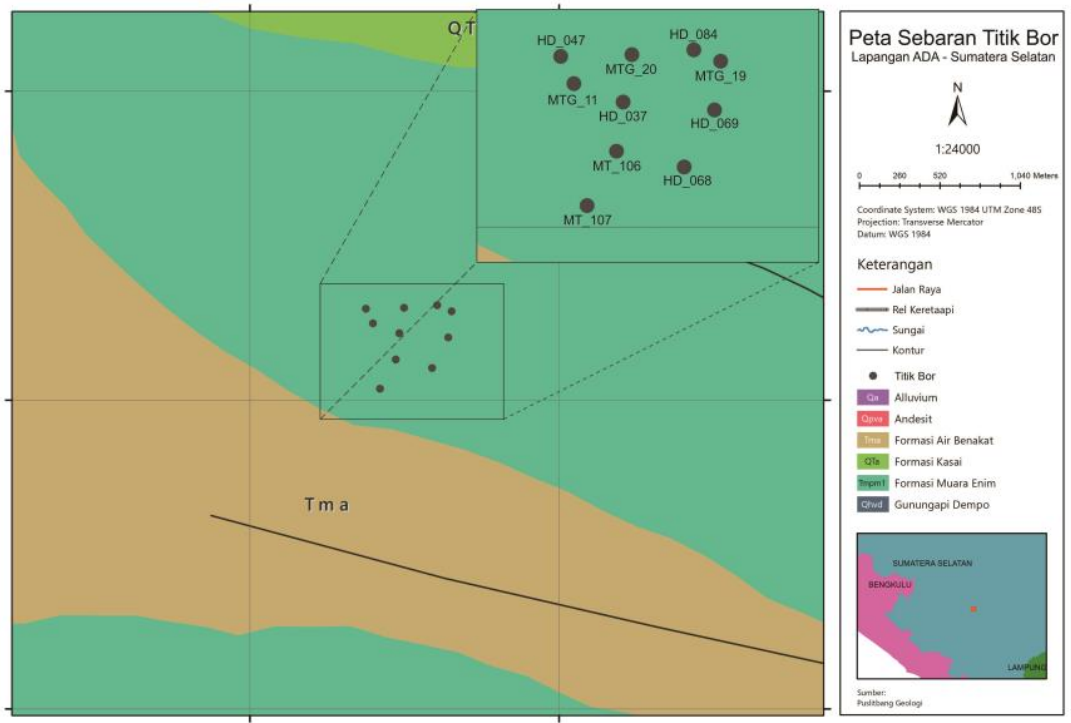

Gambar 8. Peta Sebaran Titik Bor Lapangan "ADA". 


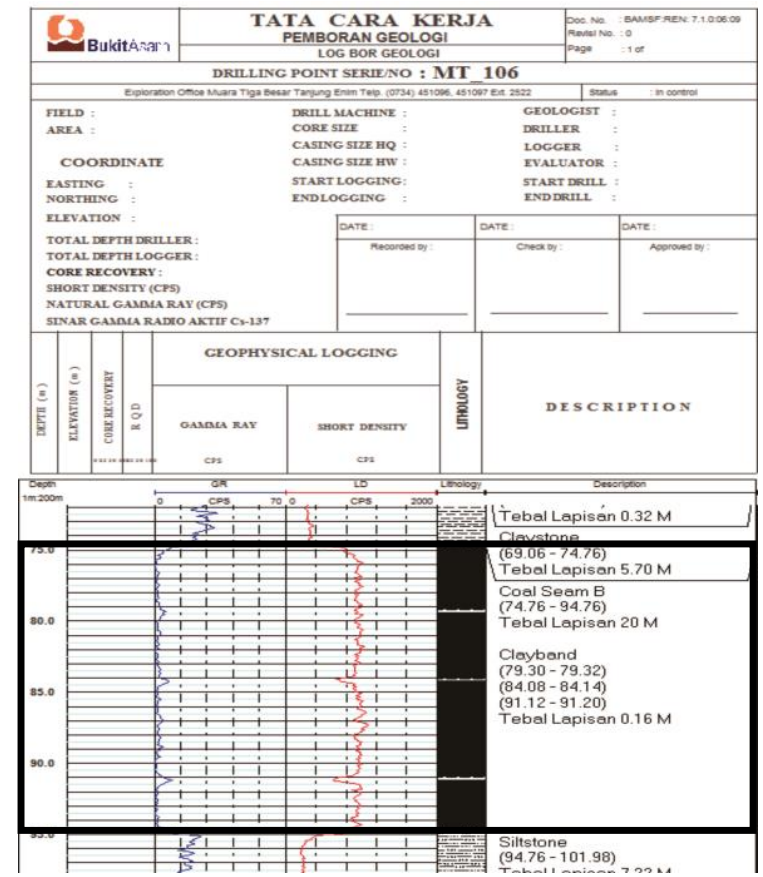

(a)

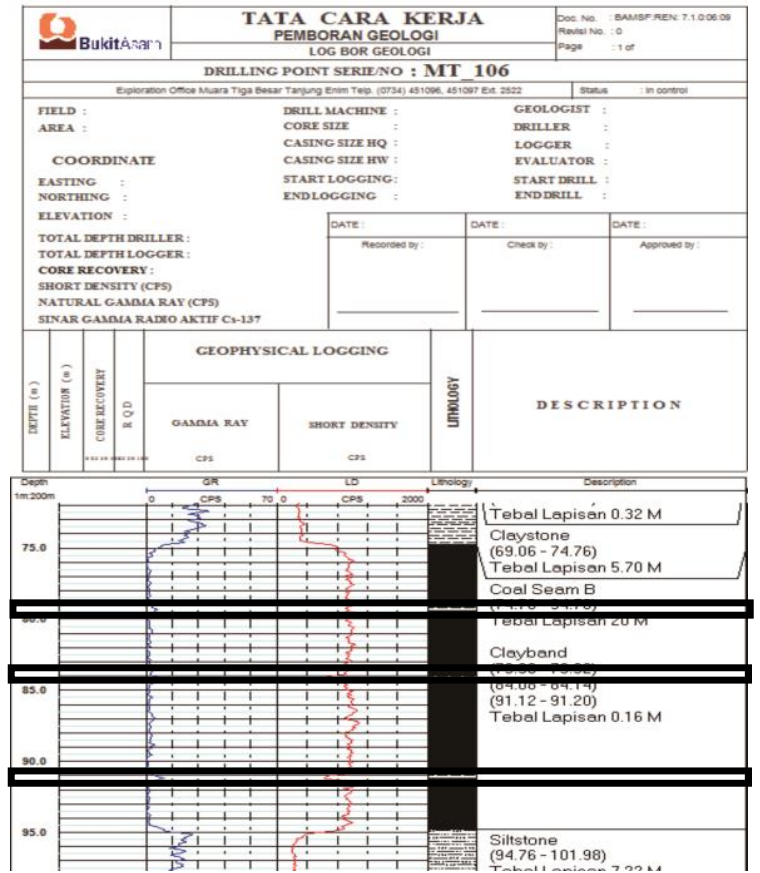

(b)

Gambar 9. Respon log gamma ray dan log density (a) pada seam batubara. (b) pada litologi clayband.

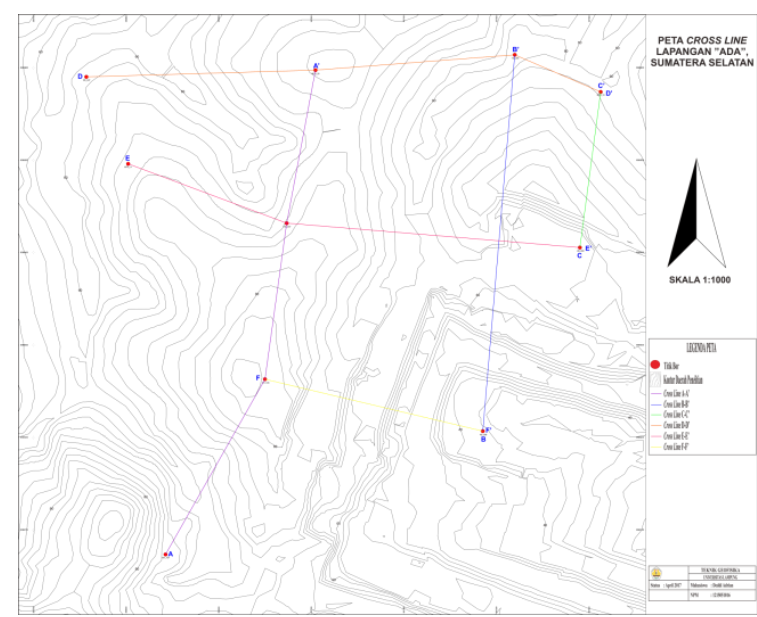

(a)
PETA TOPOGRAFI

LAPANGAN "ADA", SUMATERA SELATAN

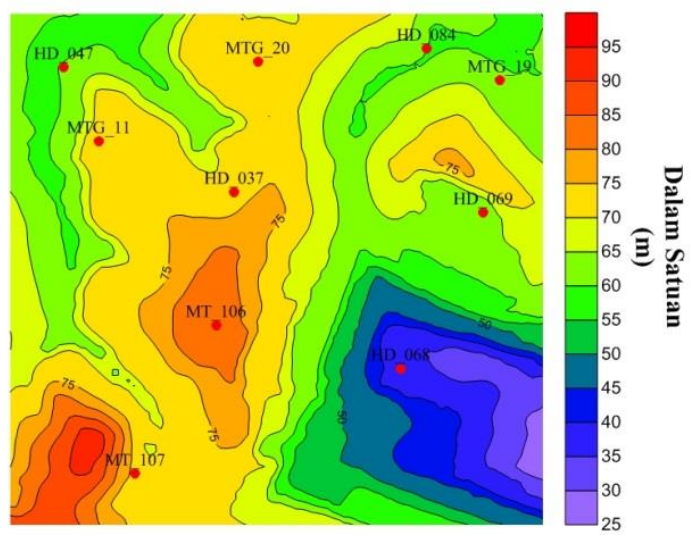

(b)

Gambar 10 (a). Peta cross line Lapangan "ADA", Sumatera Selatan. (b) Peta Kontur Topografi Lapangan "ADA", Sumatera Selatan. 


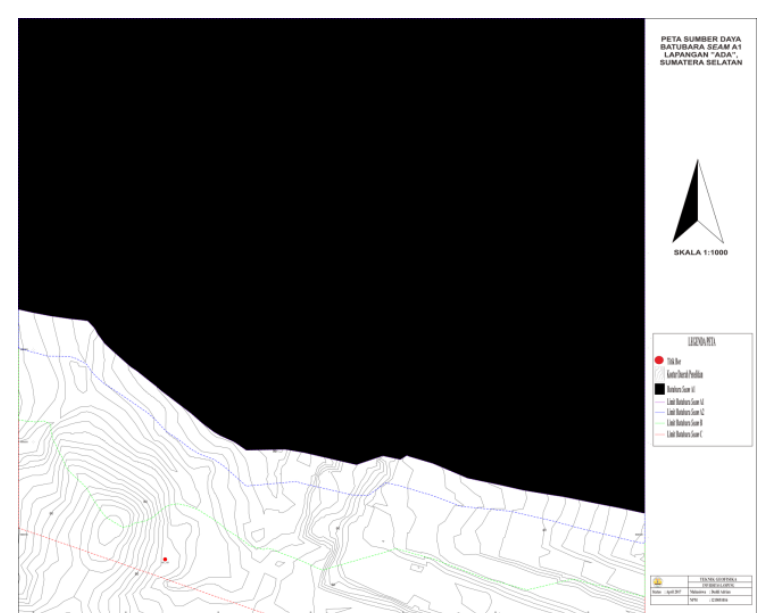

(a)

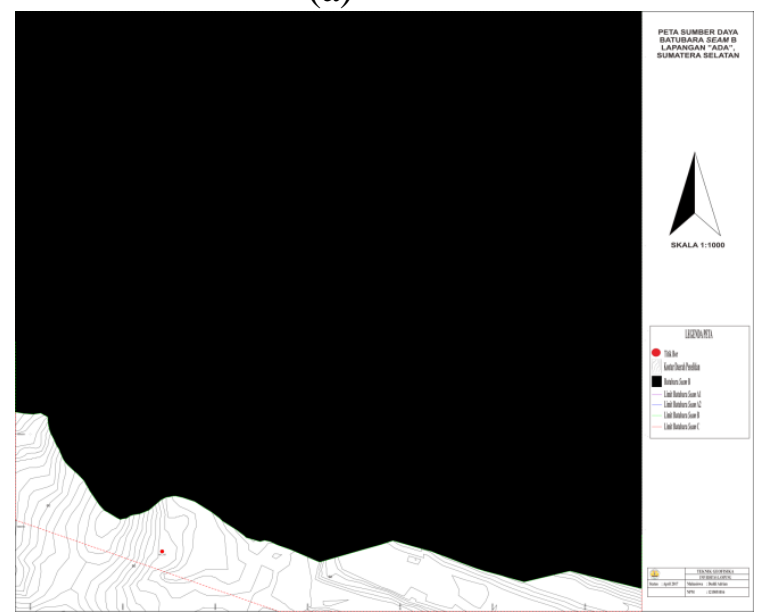

(c)

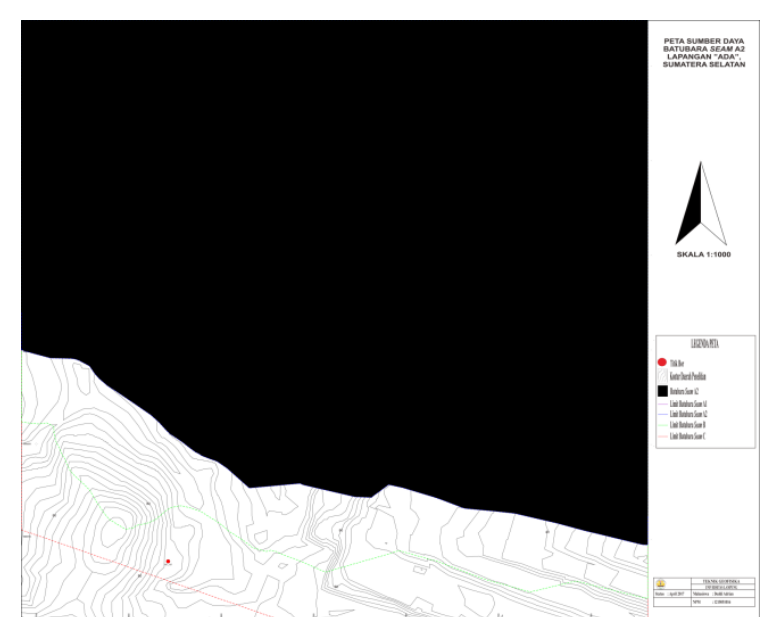

(b)

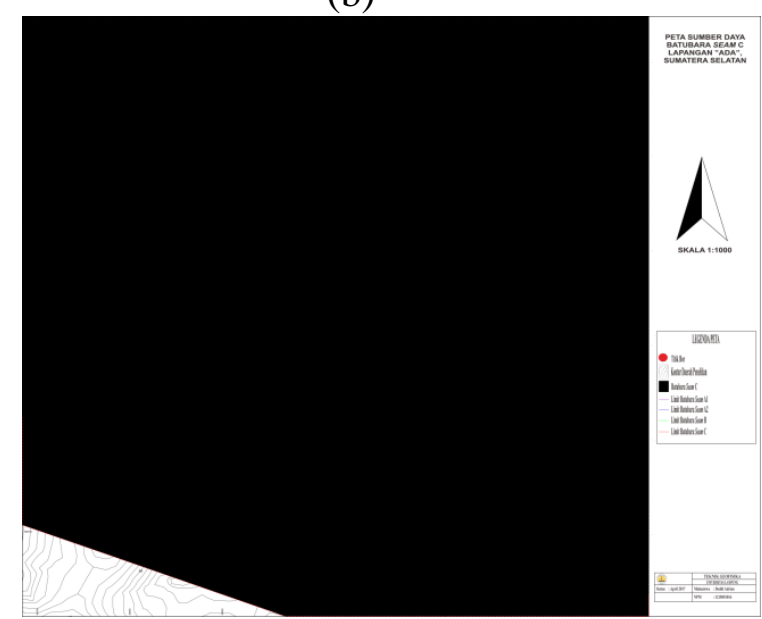

(d)

Gambar 11. Peta Sumber Daya Batubara (a) Seam A1 Lapangan "ADA", Sumatera Selatan. (b) Seam A2 Lapangan "ADA", Sumatera Selatan. (c) Seam B Lapangan "ADA", Sumatera Selatan. (d) Seam C Lapangan "ADA", Sumatera Selatan.

Top
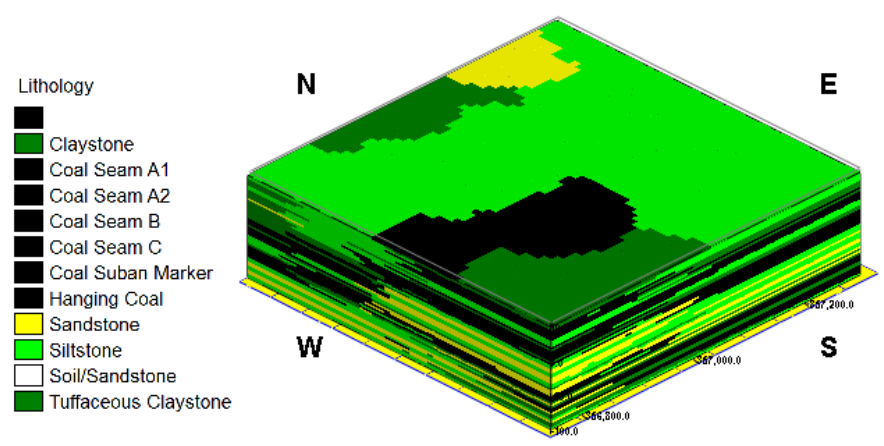

Base

Gambar 12. Model Tampilan 3D Litologi Lapangan "ADA". 


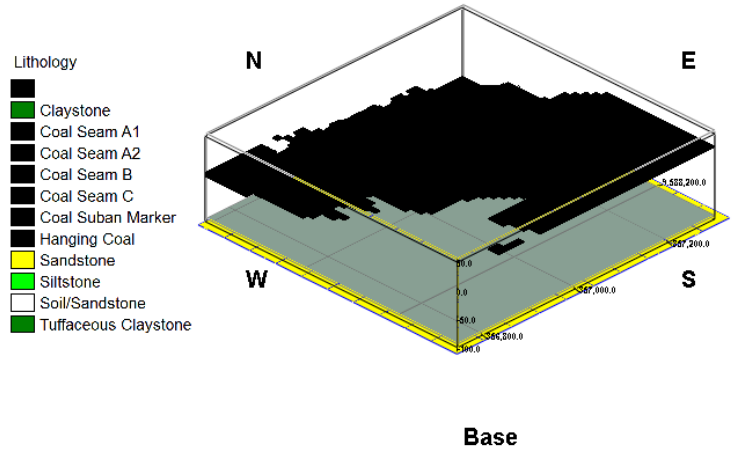

(a)

Top
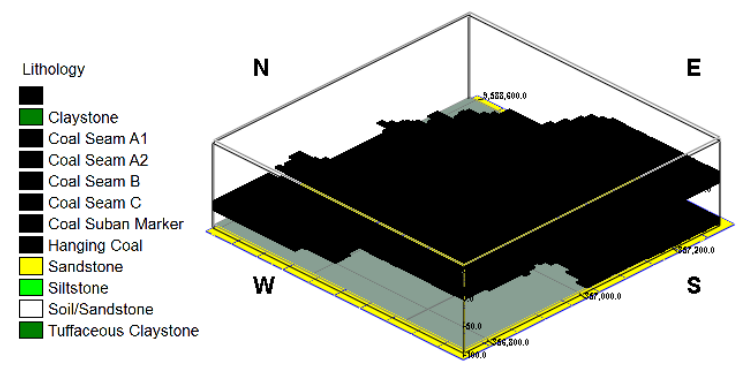

Base
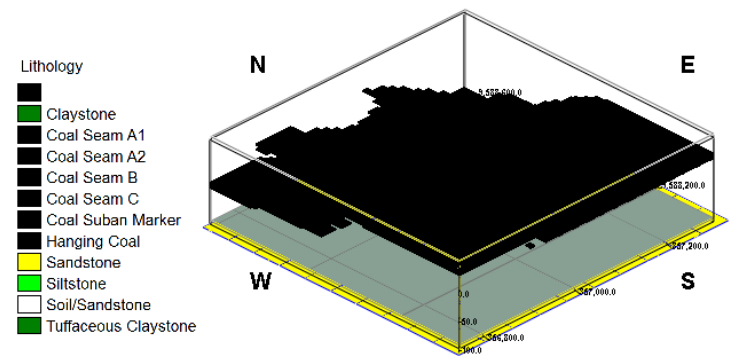

Base

(b)

Top
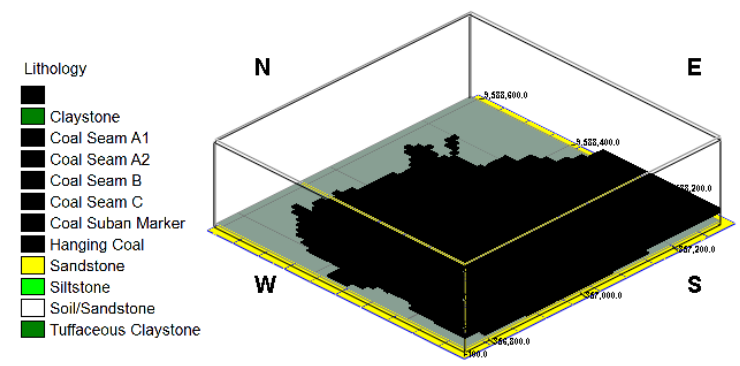

Base

(d)

Gambar 13. Model Tampilan 3D Batubara (a) seam A1 Lapangan "ADA". (b) seam A2 Lapangan "ADA". (c) seam B Lapangan "ADA". (d) seam C Lapangan "ADA". 